\title{
Blood-Brain Barrier
}

National Cancer Institute

\section{Source}

National Cancer Institute. Blood-Brain Barrier. NCI Thesaurus. Code C13194.

The mechanism for restricting the passage of charged ions and large molecules from the blood into the brain and central nervous system (CNS) by employing a unique capillary bed with tight junctions between the endothelial cells. 